Inna V. KRAVETS,

Senior Lecturer, Department of Ukrainian Studies, National University "Odessa Maritime Academy"; 8, st. Didrikhson, Odessa, 65029, Ukraine; tel.: +38 066 9486395; e-mail: kovrova@ukr.net; ORCID ID: $0000-0002-3462-2882$

\title{
UKRAINIAN COMPLEX-ABBREVIATED ERGONYMS OF THE 1920-1930S IN THE SOCIOLINGUISTIC ASPECT
}

Summary. The purpose of this study is to research the sociolinguistic features of the emergence and functioning of complex-abbreviated ergonyms in the era of revolutionary socio-political and economic transformations of the 1920-1930s. The object of study is ergonyms that functioned in the Ukrainian language of this period and had full and abbreviated forms. The subject of study is the sociolinguistic aspect of the emergence and evolution of such names. The material for study was selected from the reference book "All Odessa on 1930". The catalog of selected and analyzed ergonyms has 775 units. In the course of the study, methods of linguoculturological, semantic, word-formation, component analysis, descriptive and quantitative methods, sociolinguistic research methods were used. The result of the analysis of these ergonyms is the identification of the formation and functioning features of the language of revolutionary restructuring era on the socio-economic life.

Conclusions. In the Ukrainian language of the 1920-1930s, there was a sharp increase of ergonyms, the components of which recorded a radical change in ideological and political-economic priorities. Each multicomponent ergonym has a full and abbreviated forms. The tendency to the mandatory use of elements from the key components of full forms in complex abbreviated forms was leading in the formation of different abbreviated models. The component composition of ergonyms, naming institutions and enterprises, indicates the dominance of the state monopoly on humanitarian policy and industrial production in the country and the situation of a negative attitude of society towards private ownership of the production means. Changing official full names does not always require changing abbreviated names of institutions and enterprises. This leads to the so-called "hieroglyphization" of such names and their transformation into traditional ones.

Key words: ergonym, full name, abbreviated name, Ukrainian language of the 1920-1930s, sociolinguistic features, political and economic changes.

Статтю отримано 06.05.2019 p.

http://dx.doi.org/10.18524/2307-4558.2019.31.178517

УДК 811.111-13’371:821.111-311.2/.4

МоРозоВА Ірина Борисівна,

доктор філологічних наук, професор кафедри граматики англійської мови Одеського національного університету імені I. I. Мечникова; Французький бульвар, 24/26, Одеса, 65058, Україна;

e-mail: morpho@ukr.net; тел.: +38050 6572043; ORCID ID: 0000-0002-1905-7563

\section{GРIII0ВА Ксенія Ігорівна,}

студентка факультету романо-германської філології Одеського національного університету імені I. І. Мечникова; Французький бульвар, 24/26, Одеса, 65058, Україна;

e-mail: kseniyer@gmail.com; тел.: +38 0637508541

\section{ЛІНГВАЛЬНІ ЗАСОБИ ВИРАЖЕННЯ ЕМОТИВНОСТІ В ЖІНОЧОМУ РОМАНІ}

Анотація. Mema статті полягає у виокремленні лінгвальних засобів передачі емотивності у романі Джейн Остен "Sense and Sensibility», а також у відтворенні системи вербальних чинників емотизації художнього тексту. Об'єктом аналізу є авторський наратив і партії персонажів у зазначеному романі. Предметом є встановлення лінгвальних шляхів кодування емоцій у романі Джейн Остен “Sense and Sensibility». У результаті роботи визначено теоретичну базу, окреслено основні напрями наукового пошуку об'єктивації емотивності у романі “Sense and Sensibilityn, охарактеризовано гендерні ознаки жіночого роману як особливого художнього жанру, розглянуто категорії емотивності як специфічного психолінгвістичного феномену, виокремлено основні засоби вираження емотивності у тексті роману. Висновки. У художньому творі "Sense and Sensibility" автор вербалізує емоції на рівні персонажного діалогу героїнь і авторського наративу, де емоційна напруженість дійових осіб маніфестуються шляхом окреслення їхньої невербальної поведінки: рухів, міміки, зміни кольору обличчя тощо, а також, за допомогою прямого найменування почуття героїнь. Робиться висновок, що головною текстовою сферою об'єктивації емоцій є саме персонажний діалог, де почуття героїнь вербалізуються на різних мовних рівнях.

Ключові слова: гендер, жіночийроман, емотивність, авторський наратив, персонажний діалог.

Постановка проблеми. Статтю присвячено проблемі віддзеркалення емотивного навантаження партій персонажів і авторського наративу роману Джейн Остен "Sense and Sensibility». Дослідження художнього тексту в останнє десятиріччя характеризується багатовимірністю ана- 
лізу, а також постійним розширенням обсягу об'єкта наукового зацікавлення. У фокусі безперечного інтересу науковців завжди перебували й перебувають проблеми кодування чуттєвої сфери у вербальні знаки, бо висловлюючи будь-яке повідомлення, людина не байдужа до того, що говорять.

Питання вербальної модифікації у відображенні емоцій та почуттів у мові вивчалося ще в класичних працях з мовознавства. В. фон Гумбольдт, В. Вундт, О. О. Потебня, Ш. Балі. Протягом XX ст. науковці досліджували емотивність у художніх творах. Ці розробки поширилися та набули нових ознак в аспекті мовного, різнорівневого відображення емоцій. Дослідження саме роману Джейн Остен "Sense and Sensibility) (укр. (Розум і почуття)) мотивоване як назвою роману, так і тим чинником, що, за визначенням М. М. Бахтіна жіночий роман “є згущенням емоцій та яскравим прикладом їхнього відображення) [1, с. 456].

Питання віддзеркалення емоцій і почуттів у художньому тексті розробляються також сучасними дослідниками в семантичному (Б. Волек, Я. В. Гнєзділова, К. Годар), функційно-комунікативному (С. Фасел, І. І. Шахновська, В. І. Шаховський), когнітивному (С. В. Гладьо, А. П. Мартинюк), лінгвокультурологічному (А. Вежбицька, О. В. Дімітрова, А. Огаркова), психолінгвістичному (Н. В. Вітт, В. М. Грідін, О. Ю. Кабановська) та інших аспектах.

Однак, віддаючи належне науковим здобуткам зазначених та інших мовознавців, звернемо увагу на те, що багато параметрів об'єктивації емотивності у мовних знаках потребують подальшого розгляду.

Актуальність проведеної роботи випливає із загальної лінгво-гносеологічної важливості, проблеми розкриття природи емотивності, а також зумовлена практичною необхідністю аналізу художнього тексту та ступеню його емоційного впливу на гіпотетичного читача.

Формулювання завдання. Мета дослідження полягає у виокремленні лінгвальних засобів передачі емотивності в романі Джейн Остен "Sense and Sensibility", а також у відтворенні системи вербальних чинників емотизації художнього тексту. Об'єктом аналізу є авторський наратив і партії персонажів у зазначеному романі. Предметом $\mathrm{\epsilon}$ визначення лінгвальних шляхів кодування емоцій у цьому романі. Із поставленої в роботі мети випливають завдання, які необхідно вирішити для ії досягнення: визначити теоретичну базу, окреслити основні напрями дослідження об'єктивації емотивності в романі “Sense and Sensibility», охарактеризувати гендерні ознаки жіночого роману як особливого художнього жанру, розглянути категорії емотивності як специффічного психолінгвістичного феномену, виокремити основні засоби вираження емотивності в зазначеному творі. Матеріалом дослідження є 452 речення авторського наративу та 637 емотивно навантажених реплік Маріанни та Елінор, дібраних способом суцільної вибірки із тексту дослідженого роману.

Предмет, мета і завдання роботи визначають методи проведення наукової розвідки, які забезпечують холістичний розгляд проблеми, що досліджується. Крім загальнонаукових методів (аналіз, синтез, індукція, дедукція), у роботі застосовано специфічні лінгвістичні методи контекстуального, поверхнево-структурного, комунікативно-інтерпретативного аналізу, а також метод лінгвістичного спостереження.

За словами Е. Косеріу, “...без урахування емоційного чинника від притаманного людині первинного досвіду від його живого тіла залишиться тільки скелет» [3, с. 252]. К. Шнайдер та деякі інші сучасні лінгвісти вважають, що будь-якому висловлюванню притаманне вираження емоцій, тобто повідомлення мовця може бути позитивно емоційно-забарвленим, негативним або індиферентним. Інакше кажучи, емоції присутні в будь-якому висловлюванні людини. Зазначимо, що в Швейцарії є відома спеціальна дослідницька організація, яка вивчає емоції в галузі мовознавства: International Society for Research on Emotions (ISRE), - а також функціонує психолінгвістичний центр: The International Grid Research Consortium (2005). Отже, вивчення емоцій людини та категорії емотивності залишається актуальною мовознавчою проблемою. У наступній роботі емотивність розуміють у загальноприйнятному для психології сенсі: як “суб'єктивну реакцію, що характеризується процесом збудженням нервової діяльності людини» [7, с. 124]. Попри велике розмаїття наукових підходів до проблеми об'єктивації емотивності та емоційності в художньому творі, зазначимо певні прогалини, що спостерігаються у вивченні емоції крізь призму гендеру.

Сьогодні термін (гендер) вживають для опису всіх перетворень у суспільстві та державі, оскільки саме на них якраз впливають особистості чоловіка й жінки та їхні стосунки $[5$, c. 11].

Гендерні ознаки мовної картини світу - це сутнісні прояви пізнання світу крізь призму чоловічого й жіночого бачення, а також вплив статі на мовну практику та мовну поведінку. Гендерні відношення у мові зафіксовано у вигляді мовних стереотипів, які накладають відбиток на людину, в тому числі й на її мовленнєву особистість, а також на процеси її мовної соціалізації. Зрозуміло, що жінка та чоловік внутрішньо переживають і зовнішньо виражають емоції по-різному. Відомо, що навіть у побутовій комунікації прийняті певні гендерні стереотипи проявів емоцій. Вивчаючи гендерну поведінку дітей молодшого шкільного віку, дослідники окреслюють 
орієнтири, згідно з якими виховують хлопчиків і дівчат. Сльози, бурхливий сміх дозволяють і не засуджують у дівчат, утім, така поведінка призводить до різкої критики вихователів щодо виявлення емоцій у хлопчиків. Головним аргументом при цьому виступає така теза: «Ти ж майбутній чоловік, ось і поводься відповідно» $[11$, с. 45].

Різноманітні переживання почуттів зовнішньо проявляються у специфбічному виразі обличчя, так званій емоційній масці, позі, інтонації голосу. Таких емоційних станів багато, а кожному 3 них властивий свій набір психологічних характеристик і особливостей зовнішніх ознак. Проте психологи вирізняють, залежно від аспекту розгляду, фундаментальні або базові емоції, кількість яких варіюється. До основних емоційних станів, згідно з думкою К. Ізарда, варто відносити інтерес, радість, здивування, страждання, гнів, страх, сором та ін. [2, с. 340]. Наприклад, емоція здивування є короткочасною емоційною реакцією на раптові події, вона не має чітко вираженого позитивного або негативного забарвлення. У момент виникнення здивування гальмує всі попередні емоції та спрямовує увагу на подію, яка її спричинила [4, с. 63]. Водночас, на думку А. Калімуліної, доцільно диференціювати більше двадцяти видів фундаментальних емоцій: “жах, гнів, лють, відраза, радість, здивування, печаль, любов, бажання, презирство, сором'язливість, страждання, горе, ненависть, цікавість, щастя тощо» [6, с. 4]. У нашому дослідженні ми не фокусуємо увагу на окремих видах емоційного стану людини, а концентруємо її на засобах лінгвальної репрезентації емоцій у художньому творі взагалі.

Вибір жіночого роману Джейн Остен "Sense and Sensibility» як дослідницької платформи дає прекрасну можливість розглянути жіноче авторське бачення об'єктивізації емоцій у жіночих партіях. Загальновідомо, що Джейн Остен посідає почесне місце фундатора (жіночої прози) разом із Шарлотою Бронте й кількома менш відомими письменницями. Джейн Остен ввела в літературу Британії (жіночу тему», пишучи про жінок і для жінок. (ЖЖіночий) роман епохи Вікторіанства є дзеркалом взаємин чоловіка й жінки і являє собою значну форму самовираження його творців. Своєрідність формування та втілення жіночої теми в англійському вікторіанському романі значною мірою зумовила творчість Дж. Остен. Не підпадаючи під хронологічні межі вікторіанської епохи, письменниця, тим не менш, досить органічно вписується в її соціокультурний та літературний контекст. Ї̈̈ творчість зіграла ключову роль у формуванні (жіночої) прози вікторіанської епохи, зробивши помітний вплив на твори послідовниць [10, с. 45].

Сюжет роману Джейн Остен "Sense and Sensibility» побудований навколо любовних історій двох сестер Елінор і Маріанни. Коли батько вмирає, маєток переходить до Джона і родина залишається з вельми скромними засобами для існування. Роман розповідає про подальше життя сестер Дешвуд у маєтку далекого родича, де кожна переживає сердечну драму. Ж романі, Елінор і Маріанна переживають по-різному, бо по-різному сприймають навколишній світ. Старша - крізь призму розумності і стриманості, Маріанна - віддаючись силі почуттів. Контраст характерів сестер зменшується, коли обидві вони знаходять любов і сімейне щастя.

Першу чернетку твору у формі роману в листах (епістолярна форма) авторка написала ще на початку 1795 року, коли їй було 19 років. Назва книги мала бути (Елінор і Маріанна». Однак пізніше вона змінила форму розповіді і назвала твір (Розум та Почуття), використовуючи антитезу, з одного боку, і фонетичну гру слів - 3 іншого. Якщо "sense» (розум) символізує холодний розрахунок, логіку, здоровий глузд, то “sensibility» (почуття) позначає чуттєвий аспект життя персонажів, їх закоханість, приязнь, ненависть тощо. Отже, головний конфлікт роману відбувається внаслідок боротьби розуму і сердець головних героїв. Елінор - старша із сестер - окреслена як розумна, стримана Вона розуміє суспільний обов'язок і має відчуття турботи за життя близьких до неї людей. Маріанна, молодша, репрезентує риси чуттєвості, емоційної імпульсивності юнацького романтизму. У той час, як Елінор приховує свої почуття до Едварда, Маріанна, не соромлячись, показує свою любов. Героїні Джейн Остен відповідають традиційному вікторіанському ідеалу жіночності: вони добре виховані, освічені, здатні глибоко відчувати, вірні й постійні, наділені любов'ю до природи та читання, мають приємну зовнішність, лагідний характер. Вони усвідомлюють і приймають свій підлеглий статус, соціальну та статеву перевагу чоловіків, домінуючих у суспільстві.

У комунікативній ситуації наративної структури художнього тексту аналогом мовця $є$ не сам автор-письменник, а образ автора, точніше - наратор. Художній дискурс, представлений в романі, об'єктивується на двох рівнях у вигляді авторського наративу і персонажних партій дійових осіб. Зрозуміло, що розгляд емотивного навантаження образів головних героїв обов'язково потребує аналізу не тільки саме мовленнєвих зразків Маріанни й Елінор, але й дослідження авторського наративу, за допомогою якого читач знайомиться не лише з головними подіями роману, а також із почуттями та переживаннями героїнь. Таким чином, читач сприймає відображення сюжету й емоційну атмосферу твору крізь призму авторського світобачення. Саме автор у своєму монолозі прямо або імпліцитно окреслює переживання дійових осіб. Очами автора читач бачить, що герої перебувають у конфлікті, обуренні, дуже задоволені або здивовані. Наприклад: "Oh that they would! cried Marianne, her eyes sparkling with animation, and her cheeks glowing with the delight of such imaginary happiness» [9, c. 111]. 
3 наведеного прикладу зрозуміло, що Маріанна дуже радіє. Джейн Остен описує їі очі, які сяють від радісного збудження, її щоки червоніють від радощів і щастя. Звідси, дізнаємося про те, що Маріанна відчуває емоцію щастя: «Elinor's lips had moved with her mother's, and, when the moment of action was over, she wished that she had shaken hands with him too. But it was then too late, and with a countenance meaning to be open, she sat down again and talked of the weather» [9, с. 430]. Тут емоція розчарування показана у поєднанні прямого зображення невисловлених Елінор слів і авторського опису її розчарування.

Таким чином, саме автор є центром системи просторово-часових координат твору, а також механізму сюжетного руху.

У своєму дослідженні лінгвальне відтворення емотивності у романі Джейн Остен „Розум та Почуття) розглянуто за наступним принципом. Усі засоби передачі почуттів героїв умовно розподілено на вербальні та невербальні. Оскільки йдеться про художній дискурс для читача, вищенаведені засоби будуть вербальними. Запропонований підхід залучено для практичних цілей відокремлення немовленнєвих дій віртуальних співрозмовників, як це показано автором (почервоніла, руки тремтіли, очі розширилися) і мовленнєвих подій, які ми розуміємо як персонажний діалог і авторське пряме найменування емоцій (здивувалася, прогнівалася, вибухнула щастям тощо).

Система художніх образів у романі “Sense and Sensibility» має дзеркальний характер і зображена так, як її бачить наратором-автор. Читач знайомиться із двома молодими жінками: Елінор та Маріанною - та їхніми партнерами чоловіками. Елінор - та сама героїня, яка постійно відчуває величезну відповідальність за свою сім'ю і друзів. Вона ставить їхній добробут та інтереси вище власних і пригнічує свої сильні почуття таким чином, що оточуючі вважають iї байдужою та нездатною на сильні почуття. Маріанна - предмет поклоніння полковника Брендона і містера Віллоубі. Їй подобається молодий, привабливий і романтичний Віллоубі, i вона не приділяє особливої уваги більш зрілому та стриманому полковнику. 3 усіх героїв емоції Маріанни розкрито найглибше протягом розгортання сюжетних ліній роману. Пізніше вона вирішує, що ї̈ поведінка має бути схожою з поведінкою старшої сестри. Зрозуміло, що обидві дівчини не індиферентні у своїх судженнях, і авторка не байдужа до них.

Розглянемо, яким чином зображено в романі віддзеркалення емоцій, які переживають героїні. У цьому дослідженні проведено аналіз об'єктивації емоцій в персонажному діалозі твору, тобто емотивні висловлювання за принципом їхнього функціонування в діалозі та авторському наративі. Окремо розглянуто умовно-невербальні засоби репрезентації емоцій: як це робить авторка в аспекті окреслення жіночих рухів, міміки, зміни кольору обличчя тощо. Таким чином, мова йде про кінетико-таксемний рівень вираження емоцій головними героїнями роману. Засоби вираження емоцій в романі розглянуто в наступних текстових сферах функціонування: в персонажному діалозі героїнь і в авторському наративі, які, між іншим, розглянуто як прямі найменування емоцій, що переживають героїні (гнів, здивування, щастя тощо) та опосередковане (шляхом зображення невербальних рухів дійових осіб) (див. рис. 1).

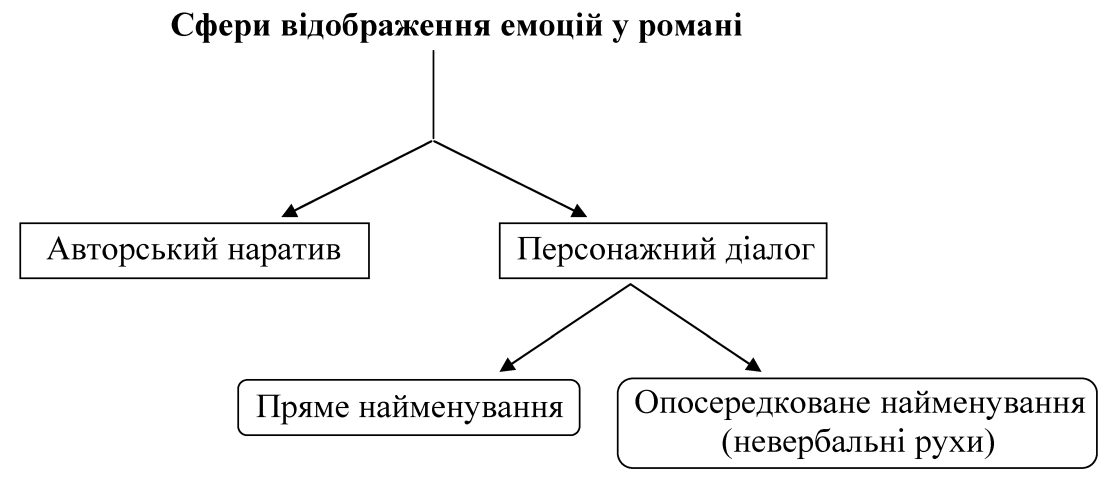

Рис. 1. Функціонування емотивності в персонажному діалозі та авторському наративі

\section{Приклади до рис. 1:}

1. Персонажний діалог

1.1. Esteem him! Like him! Cold-hearted Elinor! Oh! worse than cold-hearted! Ashamed of being otherwise. Use those words again, and I will leave the room this moment [9, c. 23];

1.2. Marianne, cried her sister, how can you say so? How can you be so unjust? [9, c. 108];

1.3. Oh! beyond anything great! What brother on earth would do half so much for his sisters, even if REALLY his sisters! And as it is - only half blood! - But you have such a generous spirit! [9, c. 10]. 
У репліках сестер, спрямованих від одної до іншої, Маріанна вибухає обуренням, що передають чотири окличних речення, організованих у ланцюжок. Усі зазначені речення прості, еліптичні, лінійно короткі; вони вказують на високу ступінь збудження головної героїні.

2. Авторський наратив. Пряме найменування

2.1. "What felt Elinor at that moment? Astonishment, that would have been as painful as it was strong, had not an immediate disbelief of the assertion attended it. She stood firm in incredulity, and felt in no danger of an hysterical fit, or a swoon" [9, c. 156];

2.2. "Her feelings were strong; but she knew how to govern them" [9, c. 6];

2.3. "She was sensible and clever; but eager in everything: her sorrows, her joys, could have no moderation» [9, c. 6].

Автор прямо вказує на тип емоцій, які переживає сестра Елінор. Це здивування, яке є болячим і сильним. Вона, за словами наратора, перебуває на межі істерики та ледве не втрачає свідомість.

\section{3. Опосередковане відображення емоцій}

3.1. "Oh that they would!" cried Marianne, her eyes sparkling with animation, and her cheeks glowing with the delight of such imaginary happiness" [9, c. 111];

3.2. Elinor's lips had moved with her mother's, and, when the moment of action was over, she wished that she had shaken hands with him too. But it was then too late, and with a countenance meaning to be open, she sat down again and talked of the weather [9, c. 430];

3.3. He wished her good morning and her hands trembled [9, c. 78].

У наведених прикладах зображені очі, які палають збудженням; щоки, які червоніють від радощів; вуста, що рухаються у невисловленій журбі; руку дівчини, що тремтить соромлячись у присутності закоханого в неї чоловіка. Вони вказують на підсвідомі імпульси, що виникають у героїні як результат переживання емоцій.

Уже наведені вище приклади маніфестують вербальні засоби вираження емотивності в аналізованому романі. Гіпотетичний читач переймається емоціями героїнь на трьох рівнях. Поперше, в персонажному діалозі, де дівчини прямо висловлюють свої почуття, це емоційні вигуки типу - “Oh!”, “My God!”, ланцюжком заперечувальних чи стверджувальних реплік тощо. Авторський наратив наводить пряме найменування почуттів: anger, joy, happiness тощо. Крім того, окреслюючи невербальну поведінку своїх героїнь, автор опосередковано кваліфбікує їхні емоції. Характеристики кінетики, таксемики, колористики обличчя дівчат підсилюють емоційність художнього твору, надаючи вірогідінсть почуттям Маріанни й Елінор.

Висновки. Таким чином, результати проведеного дослідження свідчать, що домінуючою текстовою сфрерою об'єктивації емоцій у романі Джейн Остен "Sense and Sensibility" є персонажний діалог. Емотивні репліки героїнь загалом складають 76,8 \% порівняно до інших засобів вираження емотивності у творі - 23,2 \%. Пряме найменування автором емоцій не перевищує $14 \%$ усіх емотивних висловлювань, а опосередкована характеристика почуттів, які відчувають героїні, є мінімальною - 9,2 \% з усіх емотивних висловлювань у тексті.

Автор у своєму наративі прямо й опосередковано називає тип емоцій, які відчувають героїні. Однак головною сферою ескалації емоційного напруження художнього твору виступає персонажний діалог. Герої роману обмінюються не тільки інформаційно-навантаженими повідомленнями, але й передають один одному своє ставлення до подій роману, залучуючи до цього вербалізатори різних мовних рівнів: лексичного, фонетичного, синтаксичного. Отже, перспективу цього дослідження вбачаємо в аналізі лінгвальних засобів відображення емоцій на вказаних мовних рівнях із встановленням питомої ваги, яка серед них є панівною.

\section{Л і т е р а т р а}

1.Бахтин М. М. Собрание сочинений: в 7 т. Москва: Языки славянских культур, 2012. Т. 3. Теория романа (1930-1961 гг.). 880 с.

2. Большой психологический словарь. 4-е изд., расшир. Москва: Прайм-Еврознак, 2008. 857 с.

3. Косериу Э. Синхрония, диахрония, история. Новое в лингвистике. Москва: Изд-во иностр. лит., 1963. Вып. III. C. $143-346$.

4. Макаров М. Л. Основы теории дискурса. Москва: Гнозис, 2003. 280 с.

5. Морозова І. Б. Парадигматичний аналіз структури і семантики елементарних комунікативних одиниць у світлі гештальт-теорії в сучасній англійській мові: монографія. Одеса: Друкарський дім, 2009. 384 с.

6. Основи теорії тендеру: навч. посіб. Київ: К.І.С., 2004. 536 с.

7. Седов К.Ф. Дискурс и личность: эволюция коммуникативной компетенции. Москва: Лабиринт, 2004. $320 \mathrm{c}$.

8. Толковый словарь психиатрических терминов: около 3000 терминов / ред. С. Н. Боков. Ростов-на-Дону: Феникс, 1996. 496 с.

9. Austen J. Sense and Sensibility / with an introd. by S. Perkins. London, 1978. 459 p.

10. Jary D., Jary J. Sociology: Web-Linked Dictionary. Mishawaka: Collins, 2000. 285 p.

11. Grice H. P. Logic and conversation. Syntax and semantics / ed.: P. Cole, J. L. Morgan. New York: Academic Press, 1975. Vol. 3: Speech Acts. P. 41-58.

12. Schultz D. Theories of personality. Monterey: Brooks / Cole Publishing Company, 1976. 372 p. 


\section{References}

1.Bakhtin, M. M. (2012) Collected works: in 7 vol. [Sobranie sochineniy: $\mathrm{v} 7$ t.], Languages of the Slavic cultures Publishing House, Moscow, vol. 3, 880 p.

2.Large psychological dictionary, 4th ed., extend. (2008) [Bol'shoy psikhologicheskiy slovar', 4-oe izd., rasshir.], Prime-Euroznak, Moscow, 857 p.

3. Coseriu, E. (1963), "Synchrony, diachrony, and evolution", New in linguistics ["Sinkhroniya, diahroniya, istoriya", Novoye v lingvistike], Foreign literature Publishing House, Moscow, vol. 3, pp. 143-346.

4. Makarov, M. L. (2003), Basics of discourse theory [Osnovy teorii diskursa], Gnozis Publishing House, Moscow, $280 \mathrm{p}$.

5. Morozova, I. B. (2009), Paradigmatic analysis of the structure and semantics of elementary communicative units in the light of Gestalt theory in contemporary English: monograph [Paradyhmatychnyi analiz struktury ta semantyky elementarnykh komunikatyvnykh odynyts u svitli heshtalt-teorii $v$ suchasnii anhliiskii movi: monohrafiia], Printing House, Odessa, 384 p.

6. Fundamentals of the theory of gender: Study guide (2004) [Osnovy teorii genderu: navch. posibnyk], K.I.C. Publishing House, Kiev, 536 p.

7. Sedov, K. F. (2004), Discourse and personality: the evolution of communicative competence [Diskurs $i$ lichnost: evolyutsiya kommunikativnoy kompetentsii], Labyrinth, Moscow, $320 \mathrm{p}$.

8. Explanatory Dictionary of Psychiatric Terms (1996) [Tolkovyy slovar' psikhiatricheskikh terminov], ed.

S. N. Bokov, Phoenix Publ. House, Rostov-on-Don, 496 p.

9. Austen, J. (1978), Sense and Sensibility, Oxford UP, London, 459 p.

10. Jary, D., Jary, J.' (2000), Sociology: Web-Linked Dictionary. Mishawaka: Collins, 2000.

11. Grice, H. P. (1975), "Logic and conversation", Syntax and semantics / ed.: P. Cole, J. L. Morgan, Academic Press, New York, vol. 3 (Speech Acts), pp. 41-58.

12. Schultz, D. (1976), Theories of personality, Brooks / Cole Publishing Company, Monterey, 372 p.

\section{МоРозоВА Ирина Борисовна,}

доктор филологических наук, профессор кафедры грамматики английского языка Одесского национального университета имени И. И. Мечникова; Французский бульвар, 24/26, г. Одесса, 65058, Украина; e-mail: morpho@ukr.net; тел.: +38050 6572043; ORCID ID: 0000-0002-1905-7563

\section{ЕРІІОВА Ксения Игоревна,}

студентка факультета романо-германской филологии Одесского национального университета имени И. И. Мечникова; Французский бульвар, 24/26, г. Одесса, 65058, Украина; e-mail: kseniyer@gmail.com; тел.: +38 0637508541

\section{ЛІНГВАЛЬНЫЕ СРЕДСТВА ВЫРАЖЕНИЯ ЭМОТИВНОСТИ В ЖЕНСКОМ РОМАНЕ}

Аннотация. Цель статьи заключается в определении лингвальных средств передачи эмотивности в романе Джейн Остен "Sense and Sensibility», а также в воссоздании системы вербальных факторов эмотизации художественного текста. Объект анализа - авторский нарратив и партии персонажей в указанном романе. Предметом является установление лингвальных путей кодирования эмоций в тексте этого романа. В результате проведённой работы определена теоретическая база, обозначены основные направления научного поиска объективации эмотивности в романе "Sense and Sensibility", охарактеризованы гендерные признаки женского романа как особого художественного жанра, рассмотрены категории эмотивности как специфического психолингвистического феномена, выделены основные средства выражения эмотивности в данном произведении. Выводы. B романе “Sense and Sensibility” автор вербализует эмоции на уровне персонажных диалогов героинь и авторского нарратива. Эмоциональное напряжение действующих лиц манифестируется путём определения их невербального поведения: движений, мимики, изменения цвета лица и другого, - а также с помощью прямого наименования чувств героинь. Главной текстовой сферой объективации эмоций является именно персонажный диалог, где чувства героинь вербализуются на разных языковых уровнях.

Ключевые слова: гендер, женский роман, эмотивность, авторский нарратив, персонажный диалог.

Iryna B. MOROZ0VA,

Doctor of Philological Sciences (Grand PhD), Full Professor; Chair of English Grammar; Odessa I. I. Mechnikov National University; 24/26 Frantsuzskiy blvd., Odessa, 65058, Ukraine;

tel.: +380506572043; e-mail: morpo@ukr.net; ORCID ID: 0000-0002-1905-7563

Ksenia I. YERSHOVA,

Student of Faculty of Romance and Germanic Philology; Odessa I. I. Mechnikov National University; 24/26 Frantsuzskiy blvd., Odessa, 65058, Ukraine; tel.: +380637508541; e-mail: kseniyer@gmail.com

\section{LINGUAL MEANS OF EXPRESSING EMOTIVITY IN FEMALE NOVEL}

Summary. The presented work looks at the problem of the gender aspect of objectivizing emotions on different language levels in the novel by Jane Austen "Sense and Sensibility". The main objective of the presented investigation consists in singling out different lingual means of conveying emotivity in the novels studied. The author has also analyzed the system of characters as depicted in the novel as well as the verbal and non-verbal factors of emotisation of the literally text. The object of an investigation is the author's narrative and personages' parties in the given novel. The subject of analysis is defining linguistical ways of codifying emotions in the novel by Jane Austen "Sense and Sensibility». The authors concretize the term "emotivity" in the aspect of the stated problem characterized the gender peculiarities of the feminine novel as a special psycho-linguistical phenomenon. In the process of analysis, the main means of expressing emotivity are found with establishing the dominant type among them. The actual corpus of material for research counts 637 emotions loaded remarks of Marianna and Elinor 
selected consecutively from the novel "Sense and Sensibility" and accompanied samples of the author's narrative emotionally loaded. The carried out investigation results in the conclusion as to dominating sphere of the emotions representation. There are also found out other ways of conveying emotions.

Key words: gender, female novel, emotivity, author's narrative, personage's dialogue.

Статтю отримано 12.03.2019 р.

http://dx.doi.org/10.18524/2307-4558.2019.31.178522

УДК [811.161.1+811.581]'373.74:316.776.33:747.012:643

ШІУМАРИА Татьяна Фёдоровна,

кандидат филологических наук, доцент кафедры русского языка Одесского национального университета имени И. И. Мечникова; Французский бульвар, 24/26, г. Одесса, 65058, Украина;

e-mail: shumarina2010@mail.ru; тел.: +38 067 3779936; ORCID ID: 0000-0001-7383-7707

\title{
МА Синьюэ,
}

бакалавр филологического факультета Одесского национального университета имени И. И. Мечникова;

Французский бульвар, 24/26, г. Одесса, 65058, Украина;

e-mail: 2716591206@gg.com; моб.: +38 073290925

\section{ФРАЗЕОЛОГИЗМ КАК ЭЛЕМЕНТ СУГГЕСТИВНОГО ДИЗАЙНА}

\begin{abstract}
Аннотация. В статье описана русская и китайская гастрономическая фразеология в лингвокульторологическом и прикладном аспектах. Объект исследования: национально-культурная специфика фразеологии русского и китайского языков. Предлет исследования: национально-культурное своеобразие суггестивной гастрономической фразеологии в этническом дизайн-проекте. Целью является демонстрация суггестивных возможностей гастрономических фразеологизмов в качестве составляющей дизайн-проекта на примере оформления русско-китайского предприятия общественного питания в этническом стиле. В работе используется описательный и сопоставительный методы. В результате исследования была установлена перспективность изучения фразеологических единиц в качестве элементов суггестивного интерьера. Выводы. Гастрономический фразеологизм как элемент суггестивного дизайна может использоваться в целом ряде суггестивных приёмов и рассматриваться как составляющая проектируемого информального обучения языку. Практическая иенность результатов исследования заключается в возможности оказать помощь слушателям и студентам технологических и лингвистических учебных заведений.

Ключевые слова: фразеологизм, суггестия, дизайн, информальное обучение.
\end{abstract}

Постановка проблемы. Характеризуя современные манипуляционные технологии, Г. Г. Почепцов замечает, что, когда была обнаружена восприимчивость человеческой психики к внушению, информация в форме пропаганды и агитации стала главным рычагом управления людьми $[2$, с. 120$]$. В современной лингвистике приёмы внушения (суггестия) и убеждения (аргументация) именуются манипулятивными, а процесс и результат их воздействия - манипуляцией. Путём внушения вызываются ощущения, эмоциональные состояния и поведение, адекватные манипулятивной цели, то есть достигается прогнозируемый перлокутивный эффект. Суггестивность широко распространена в политике, педагогике, в рекламе, а также в экономике, в психологии и медицине. В середине XX века появилась теория суггестивного сервиса. В настоящее время суггестивный сервис, то есть действия персонала, основанные на знании социально-психологических закономерностей взаимодействия с клиентом, умении управлять им посредством речевого воздействия с целью стимулирования к дополнительному заказу в интересах предприятия индустрии питания, широко известен и популярен. Суггестивные лингвистические средства актуальны и в сфоре инжиниринга меню - это целая область, где языковые приемы используются как средство интенсификации внушаемого воздействия. Описание блюда в меню способствует увеличению продаж. Шрифт (округлый ассоциируется со сладким), слова определённых тематических групп, например "Дом», “Семья), вызывающие ностальгические воспоминания (бабушкин хлеб, домашний кекс, старый добрый «хворост»), длина слова имеют огромное влияние на выбор блюда. Таким образом, лингвистическая составляющая суггестивного сервиса в сфере общественного питания разрабатывается, хотя нельзя не отметить крайнюю малочисленность теоретических лингвистических работ по данной проблематике (в отличие от многочисленных практических суггестивных техник). А вот очевидно находящаяся в той же плоскости и связанная с гастрономическим суггестивным сервисом проблема суггестивного дизайна предприятий питания не получила развития в сфере манипуляционных технологий. Не раскрыты и манипулятивные возможности языковых единиц как элементов суггестивно ориентированного ин- 